\title{
Sprawiedliwy rozdział świadczeń medycznych jako problem bioetyczny
}

W etyce od wieków toczą się spory o miejsce i rolę wartości sprawiedliwości w życiu człowieka. Filozofowie często diametralnie różnią się w ocenie proponowanego dla niej miejsca w hierarchii wartości, a także uzasadnieniu przyznanej jej rangi. Obecnie, w miarę postępującej globalizacji i stanowiącej jej konsekwencję atomizacji życia jednostek, na nowo odżywają antyczne spory na ten temat. Szczególną okazję ku temu stwarza dyskusja polityczna toczona również w naszym kraju o tzw. „koszyk medycznych świadczeń gwarantowanych” bądź o możliwość dodatkowego ubezpieczenia się w celu uzyskania dostępu do świadczeń ponadnormatywnych. Argumenty ekonomiczne wysuwane w trakcie tej dyskusji mają drugorzędne znaczenie, bo w odczuciu społecznym takie rozwiązania naruszają elementarne poczucie sprawiedliwości. Czymże jest w takim razie sprawiedliwość, skoro samo odczuwanie jej niedostatku kanalizuje kierunek i temperaturę toczonych dyskusji? Konsekwencją takiego zastanowienia się jest kolejne pytanie - dlaczego np. prawo wyborcze, którego zmiana również dotyczy każdego obywatela naszego państwa, nie wzbudza równie wielkiego zainteresowania społecznego? Tak się złożyło, że odpowiedzi na te pytania nie oczekujemy od polityków, choć oni głównie nadają ton toczonej dyskusji, ale właśnie od przedstawicieli nauki, którzy również w odczuciu społecznym są niejako predysponowani do wydawania sądów obiektywnych i sprawiedliwych. Nie powinno zatem dziwić zainteresowanie etyków problemem sprawiedliwego podziału usług i środków medycznych, a samo uchylanie się od rozważania tej kwestii można traktować nawet jako uchybienie etosowi życia naukowego. W żadnym wypadku nie oznacza to, że każda propozycja płynąca ze strony ludzi nauki jest racjonalna i zasługuje na natychmiastowe wdrożenie do praktyki. Podobnie nie zakładam tego, że problem uda się rozstrzygnąć jednym, krótkim wystąpieniem. W podjętym temacie zamierzam zatem przedstawić tylko niektóre stanowiska etyków dotyczące rozumienia sprawiedliwości oraz wskazać na konsekwencje ich wdrożenia do praktyki społecznej. Podjęty wywód zamyka propozycja dotyczącą możliwości reorientacji traktowania sprawiedliwego rozdziału jako problemu zewnętrznego względem podmiotu oceniającego. Tym samym, przynajmniej w moim przeko- 
naniu, ostateczną instancją rozstrzygającą możliwość zastosowania sprawiedliwych kryteriów w praktyce życiowej pozostaje sumienie. Nie ma tu znaczenia czy chodzi o decydenta ustalającego kryteria rozdziału, czy beneficjenta tylko korzystającego z rozdzielanych środków i świadczeń.

W systemie wartości, jakim kierujemy się w swym życiu, sprawiedliwość odgrywa bowiem zawsze znaczącą rolę. Jej siłę oddziaływania zauważamy zwłaszcza przy podejmowaniu decyzji oraz przy ocenie innych. Sprawiedliwość zarazem nie może występować w nadmiarze, ktoś bardzo starający się być sprawiedliwym, nadal jest tylko sprawiedliwy, z drugiej zaś strony możliwy do wyobrażenia jest stan jej niedostatku - niesprawiedliwość. Niedostatek sprawiedliwości nie musi nas bezpośrednio dotyczyć, dlatego ta wartość ma charakter najbardziej prospołeczny, nie da się bowiem jej wyobrazić bez odniesienia milczącego, do innych ludzi. Już Arystoteles zauważył tę cechę twierdząc, że „sprawiedliwość jest identyczna $z$ doskonałością etyczną, jednakże doskonałością etyczną nie samą w sobie, w znaczeniu bezwzględnym, lecz w stosunkach z innymi ludźmi”'

To właśnie odczuwany niedostatek sprawiedliwości czyni nasze życie nieprzewidywalnym, pełnym lęku o przyszłość własną i swoich bliskich. W konsekwencji sprawiedliwość nigdy nie zamyka się w wymiarze indywidualnym, a przenika całe nasze życie. Jest wartością, którą zgodnie ze schelerowskimi kryteriami należy umieścić $\mathrm{w}$ hierarchii bardzo wysoko, z racji maksymalnego spełniania wymogów możliwych do spełnienia przez wartość ${ }^{2}$, gdyż zarazem jest czasowo nieprzemijająca, obejmuje swym zasięgiem i odczuwaniem całość ludzkiej populacji, jest niezależna od wszystkich innych wartości, a uczynienie jej zadość czyni ludzi szczęśliwszymi.

\section{Sprawiedliwy czy wydolny system opieki zdrowotnej?}

Równo trzydzieści lat temu, w 1980 r. w Ałama-Acie, pod auspicjami Światowej Organizacji Zdrowia (WHO) przyjęto prospektywny program działań na rzecz poprawy warunków ochrony zdrowia obywateli w Europie. Program został upubliczniony pod jednoznacznie kojarzącym się ze sprawiedliwością tytułem: „Zdrowie dla wszystkich w 2000 roku”. W programie tym mając na uwadze stosunkowo wysoki standard życia obywateli, skoncentrowano się na podstawowej opiece zdrowotnej, upatrując w niej możliwość praktycznego zrealizowania hasła zawartego w nazwie programu. Postulowane funkcje systemów opieki miały zostać dostosowanie do potrzeb doskonalenia tej formy opieki zdrowotnej, aby sam system w przyszłości mógł:

\footnotetext{
Arystoteles, Etyka nikomachejska, w: tegoż, Dzieła wszystkie, T. 5, Warszawa 1996, s. 169.

2 Por. M. Scheler, Der Formalismus in der Ethik und die materiale Wertethik, „Jahrbuch für Philosophie und phänomenologische Forschung" 1913, Bd. I, s. 110-125.
} 
- być oparty „na zaangażowaniu społeczności lokalnych,

- być obsługiwany przez zespoły przedstawicieli różnych dyscyplin (nie tylko medycznych),

- stać się miejscem pierwszego kontaktu z całym systemem ochrony zdrowia,

- mieć wsparcie efektywnego systemu opieki specjalistycznej,

- zajmować się profilaktyką zaburzeń, promocją zdrowia i rehabilitacją,

- utrzymywać stały kontakt z każdym członkiem społeczności,

- sięgać do środowiska domowego i miejsc pracy w celu systematycznego rozpoznania czynników zagrażających zdrowiu,

- pomagać ludziom w podejmowaniu większej odpowiedzialności za ich własne zdrowie" 3 .

Z powyższego zestawienia wynika, że główną uwagę skoncentrowano już wówczas na propagowaniu stylu życia sprzyjającego zdrowiu. Okazuje się jednak, że wymaga to zapewnienia co najmniej standardowych warunków życia wszystkim obywatelom zarówno w życiu osobistym jak i społecznym. Dzisiaj po trzydziestu latach okazało się, że to zadanie przerosło możliwości nawet najbogatszych państw. Nawet formalne zabezpieczenie materialnych warunków egzystencji nie oznacza bowiem, że ludzie nagle zmienią swój styl życia i zaczną wykorzystywać otrzymane świadczenia i środki dla poprawienia własnej kondycji zdrowotnej i swoich bliskich. Znacznie częściej okazało się, że stało się dokładnie na odwrót.

Niepowodzenia w realizacji tego programu są związane z prozaiczną zależnością, o której rzadko pamiętają decydenci polityczni, że zdrowie społeczeństwa nie zależy od wielkości składki zdrowotnej, ani od zarobków personelu medycznego, ani tym bardziej od ilości instytucji wchodzących w skład systemu ochrony zdrowia, ale przede wszystkim od poziomu wykształcenia obywateli i ich zamożności. Do zadania takiego powinny być zatem w pierwszej kolejności włączone systemy oświaty, które powinny propagować alternatywne, co należy rozumieć, że bardziej prozdrowotne od dotychczasowych, style życia, w tym zwłaszcza upowszechniać wiedzę o czynnikach zagrażających życiu i zdrowiu (używki, złe odżywanie itp.) oraz dostarczać umiejętności niezbędnych dla samodzielnego eliminowania zagrożeń (np. stresu) występujących często w codziennym życiu. Kolejny kierunek działań powinien być nakierowanym na ograniczanie i eliminację występujących zagrożeń dla zdrowia, co jednak wymaga zbudowania stałego systemu monitoringu oraz sygnalizacji takich zagrożeń. Wreszcie trzeci kierunek postulowanych działań miał być skierowany na racjonalniejsze wykorzystanie już posiadanych sił i środków, czyli w konsekwencji taką reformę sys-

J. Melibruda, Od wydawcy. W: Ch.L. Sheridan, S.A. Radmacher, Psychologia zdrowia. Wyzwanie dla biomedycznego modelu zdrowia, przeł. A. Dodziuk i in., Instytut Psychologii Zdrowia PTP, Warszawa1998, s. XVII. 
temów opieki zdrowotnej, aby uczynić je mobilnymi, skuteczniejszymi i bardziej ekonomicznymi. Zasadnicze kierunki proponowanych działań miały więc uczynić życie ludzkie bardziej bezpiecznym zarówno w wymiarze indywidualnym jak i społecznym. Jednak nie było możliwym, aby zostały one zrealizowane siłami tylko służby zdrowia, a tak na ogół starano się je wdrożyć do praktyki społecznej.

Niepowodzenie w realizacji tego programu nie zniechęciło jednak przedstawicieli organizacji pomocowych jak i czynników politycznych do poszukiwania możliwości przeciwdziałania zauważalnemu wykluczeniu części obywateli nawet bogatych społeczeństw europejskich z pełnego dostępu do systemów opieki zdrowotnej. Przyczyn wzrastającego zainteresowania problematyką sprawiedliwego dostępu do opieki zdrowotnej jest zatem wiele. Szczególnie chętnie eksponowaną jest niewątpliwie widoczny kryzys na całym świecie zorganizowanych systemów opieki zdrowotnej, która staje się coraz droższa i coraz bardziej elitarna, gdyż na pełny dostęp do oferowanych usług stać tylko bogatszych lub bardziej uprzywilejowanych. Tempo wzrostu kosztów utrzymania narodowych systemów opieki zdrowotnej jest bowiem bardzo szybkie. Jeśli nie zatrzyma się tego trendu, to w niedługim czasie żadnego państwa na świecie nie będzie stać na zapewnienie swoim obywatelom szerokiego dostępu do opieki zdrowotnej. Dla przykładu, jeśli trendy wzrostowe nie zostaną zahamowane, to szacuje się, że w samych USA, że już w 2055 r. koszty opieki zdrowotnej pochłoną 100\% wytworzonego dochodu narodowego brutto ${ }^{4}$. Nic zatem dziwnego, że rozdźwięk pomiędzy oczekiwaniami, a ofertą kierowaną do przeciętnego pacjenta jest coraz bardziej widoczny, co rzutuje między innymi na pogorszenie poczucia bezpieczeństwa społecznego. Nie chodzi bynajmniej o to, że system nie spełnia swego zadania, ale o to, że nie daje żadnej rękojmi, iż będzie je spełniał w każdej sytuacji, gdy będzie potrzebna jego pomoc, a ponadto nie ponosi za to praktycznie żadnej odpowiedzialności. Pacjenta można nie przyjąć do szpitala, można odmówić wykonania dowolnego zabiegu czy operacji tłumacząc brakiem środków finansowych lub po prostu brakiem miejsca. Zauważyć jednak wypada, że równie uniwersalne zadanie spełnia np. system szkolny, który jednak od wypełniania swych zadań nie może się uchylić niezależnie od posiadanych środków i możliwości. $Z$ tego powodu mamy do czynienia $\mathrm{z}$ dwoma tendencjami wpływającymi na wzrost zainteresowania systemem ochrony zdrowia. Pierwszą przyczyną jest zapewne fakt, iż wszyscy ludzie z egzystencjalnej konieczności są pacjentami, czyli staną się elementem tego systemu, co budzi zrozumiałe i powszechne zainteresowanie jego funkcjonowaniem. Druga przyczyna tkwi w tym, że system jest również bardzo finansowo i materiałochłonny oraz stanowi stale rosnącą pozycję w budżecie każdego państwa, a stąd nieustannie podejmowane są próby obniżenia jego kapitałochłonności. Równie często jednak wzrost zainteresowania funkcjonowaniem

Tamże, s. XXVII. 
systemu tłumaczy się przyczynami leżącymi poza nim samym. $Z$ reguły wymienia się wówczas następujące powody:

1) „postępujący wzrost poszanowania naturalnych praw człowieka do właściwego rozwoju i jak najdłuższego utrzymania zdrowia rozumianego jako stan pełnej sprawności fizycznej, umysłowej i społecznej (motyw humanistyczny),

2) postępujący wzrost znaczenia zdrowia jednostki i zbiorowości ludzkich w ekonomii współczesnych państw (motyw ekonomiczny),

3) postępujący wpływ osiągnięć naukowych - zwłaszcza nauk medycznych i społecznych - zarówno na kształtowanie polityki zdrowotnej państwa, jak i na rozwój świadomości społeczeństwa w zakresie jego potrzeb zdrowotnych (motyw naukowy);

4) zwiększając się presja opinii publicznej na udostępnienie nowoczesnych i powszechnych form opieki zdrowotnej (motyw społeczno-polityczny),

5) postępująca kompleksowość organizacyjna ochrony zdrowia zwiększająca zarówno konieczność zaangażowania znacznych zasobów społecznych (ludzkich i materialnych), jak i potrzebę racjonalnego planowania rozwoju, koordynowania działalności i kontrolowania sprawności systemu ochrony zdrowia przez państwo (motyw organizacyjny)"5.

System opieki zdrowotnej jest w sposób oczywisty tworem człowieka, który powstał z określonym przeznaczeniem, które narzuca w pewien sposób wewnętrzny układ jego elementów. Konstrukcja tego systemu jest zatem warunkowana celem, dla którego został on utworzony. W ujęcie praktycznym (operatywnym) jest to więc zespół „czynności, zarządzeń, urządzeń i instytucji, którego celem są:

1) zapobieganie chorobom;

2) przedłużanie życia ludzkiego;

3) poprawa zdrowia fizycznego, psychicznego i społecznego ludności poprzez zorganizowane działanie obejmujące:

- nadzór nad warunkami środowiskowymi,

- zwalczanie chorób społecznych,

- szerzenie oświaty zdrowotnej w celu podniesienia higieny życia,

- organizowanie opieki medycznej w celu zapobiegania, wczesnego rozpoznawania i leczenia chorób oraz rehabilitacji osób chorych"6.

Przy takim ujęciu wszystkie elementy systemu są zaangażowane w realizację powyższych zadań. Jeśli jednak w obrębie sytemu lokuje się elementy, które tym zadaniom nie służą, to staje się on dysfunkcjonalny, a nawet niezdolny do ich wykonania. Cała organizacja ochrony zdrowia jest więc celowo uporządkowanym systemem „tych wszystkich poczynań, które społeczeństwo dokonuje dla zapo-

Organizacja ochrony zdrowia, pod red. J. Indulskiego, PZWL, Warszawa 1984, s. 11-12.

6 Tamże, s. 14. 
biegania, leczenia i usuwania niepomyślnych następstw chorób, w celu utrzymania zdolności fizycznych, umysłowych i społecznych ludności, przedłużania jego życia, a także zapewnienia prawidłowego rozwoju nowemu pokoleniu"7. Tak rozumiany system spełnia w zasadzie trzy odrębne grupy zadań: po pierwsze ochronę sanitarno-epidemiologiczną, po wtóre - podstawową i specjalistyczną opiekę zdrowotną oraz po trzecie - opiekę społeczną ${ }^{8}$ Zadania te są komplementarne na tyle, że każdy człowiek praktycznie znajduje się w zasięgu systemu od momentu poczęcia, aż do swojej śmierci. System ochrony zdrowia musi być także dostosowany do struktury wiekowej oraz terytorialnego rozmieszczenia ludności. Jego podatność na zmiany na ogół jednak pozostawia wiele do życzenia, co skutkuje wzrostem poczucia niesprawiedliwości co do jego funkcjonowania.

\section{Problem sprawiedliwego podziału świadczeń medycznych}

Zdrowie społeczeństwa jest więc zawsze przedmiotem zainteresowania wszystkich ludzi, a przez to bezpośrednio powiązane z poczuciem sprawiedliwości. Dlatego też podział deficytowych usług i terapii oraz zapewnienie równomiernego dostępu do nich są jednym z najtrudniejszych problemów politycznych w każdym państwie. Pełna sprawiedliwość nie wydaje się być możliwa, gdyż niektóre skomplikowane terapie wymagają choćby od pacjenta dobrej kondycji fizycznej. Typowym przykładem są tu techniki transplantacyjne. Z oczywistych powodów nie każdy potrzebujący może skorzystać z takich możliwości. Ponadto problemem jest deficyt specjalistów w niektórych dziedzinach, co powoduje, że dostęp do nich często zależy od miejsca zamieszkania potencjalnego pacjenta.

Kwestie sprawiedliwego rozdziału i dostępu do świadczeń medycznych potęgują uwarunkowania ekonomiczne. Dramatyczny wzrost nakładów na opiekę zdrowotną jest pochodną faktu, iż w liberalnym społeczeństwie stanowi ona enklawę niepodlegającą regułom gry rynkowej. Pozwala to ogółowi zachować nadzieję na sprawiedliwy, tzn. egalitarny, dostęp wszystkich ludzi do oferowanych usług. Tymczasem nadzieje na sprawiedliwość tego typu ciągle maleją z uwagi na stale rosnącą kapitałochłonność sektora medycznego.

Pełna sprawiedliwość w dostępie do usług medycznych zatem nie jest możliwa, zapewne z tego zwłaszcza powodu, że największe potrzeby mają na ogół te osoby, których wkład w finansowanie opieki zdrowotnej jest najmniejszy, czyli dzieci, osoby niepełnosprawne oraz ludzie starzy. W każdym społeczeństwie ponadto żyje wiele osób, które włożyły niemały wkład w finansowanie sektora publicznej opieki zdrowotnej, a sami nie skorzystali z niego prawie wcale, gdyż korzystają wyłącznie z płatnych placówek opieki zdrowotnej.

Tamże.

8 Tamże, s. 52-53. 
Do zagadnień związanych ze sprawiedliwością należy też kwestia obciążenia rosnącymi nieustannie kosztami usług medycznych. Modele opieki zdrowotnej na ogół premiują najsłabszych i najuboższych. Sprawiedliwość w medycynie nie jest więc tym samym, czym jest np. w ekonomii. W rezultacie istnieje powszechny dysonans pomiędzy gotowością obywateli do ponoszenia kosztów usług medycznych w skali ogólnej, a oczekiwaniem jak najwyższej jakości świadczonych usług.

Kolejny problem dotyczy rosnącego pakietu świadczeń medycznych, które z racji niezwykle wysokich kosztów stają się ogólnie trudno dostępne i chętnie przez decydentów są wliczane do tzw. pakietu usług ponadnormatywnych. Są to przeważnie terapie wymagające niezwykle skomplikowanej aparatury lub stosowania kosztownych leków. Ponadnormatywność nie ma tu nic wspólnego ze sprawiedliwością, gdyż dostęp do tych terapii jest warunkowany czynnikami zewnętrznymi. Dlatego jest to niezwykle skomplikowany problem etyczny, gdyż ze wszystkich istniejących norm prawnych i moralnych wynika potrzeba zachowania równego dostępu do świadczeń zdrowotnych. Konwencja o ochronie praw człowieka i godności istoty ludzkiej w odniesieniu do zastosowań biologii i medycyny zwana skrótowo Konwencją o prawach człowieka i biomedycynie w art. 3 „Zasada sprawiedliwego dostępu do opieki zdrowotnej” głosi: „Uwzględniając potrzeby zdrowotne oraz dostępne środki, Strony podejmą w ramach swoich właściwości, stosowne działania w celu zapewnienia sprawiedliwego dostępu do opieki zdrowotnej o właściwej jakości”'. Konwencja ta została ratyfikowana także przez Polskę. Tylko pozornie, na pierwszy rzut oka oznacza to konieczność zapewnienia równego dostępu do świadczeń medycznych. Twórcy konwencji raczej wyznaczyli kierunek działań zmierzających do tego celu. Istnieje bowiem wiele świadczeń medycznych, których kryterium sprawiedliwego dostępu nie obowiązuje. Chodzi tu przede wszystkim o tzw. medycynę kosmetyczną, jak też medycynę eksperymentalną. Postulatywny charakter zapisów o sprawiedliwym dostępie do usług medycznych aprobują także sami przedstawiciele służby zdrowia.

Przekonanie, że wszystkim ludziom należą się takie same świadczenia ze strony systemu opieki zdrowotnej wynika z założenia nie tylko równości godności wszystkich ludzi, ale także ich równości względem cierpienia. $\mathrm{Z}$ samego faktu, że każdy chory ma taką samą potrzebę wyzdrowienia nie wynika jednak, że w każdym przypadku zostaną zastosowane takie same terapie, które maja mu przywrócić utracone zdrowie. Problemem jest więc dla każdego pracownika służby zdrowia takie racjonowanie świadczeń i środków terapeutycznych, które nawet jeśli są podzielone nierówno, to w ocenie większości są wyrazem przestrzegania zasad sprawiedliwości społecznej przy ich rozdziale. Istnieją ta-

$9 \quad$ Konwencja o ochronie praw człowieka i godności istoty ludzkiej w odniesieniu do zastosowań biologii i medycyny: KONWENCJA BIOETYCZNA, „Biuletyn Biura Informacji Rady Europy. Bioetyka" 1994, nr 3. 
kie usługi i medykamenty, które są dostępne dla wszystkich potrzebujących, jak choćby powszechne szczepienia dzieci i młodzieży. Nie ma tu mowy o niesprawiedliwości, już prędzej niektóre osoby zmuszane środkami administracyjnymi do skorzystania z tej usługi, mogą się czuć jako potraktowane niesprawiedliwie. Jakie zatem środki i usługi medyczne są racjonowane?

W literaturze bioetycznej na ogół wskazuje się na trzy cechy, które musi dobro posiadać, aby być racjonowane:

1) „wartość,

2) ograniczona ilość (dostępność),

3) możliwość kontrolowania" ${ }^{10}$.

Dla każdego potrzebującego wartość środków i świadczeń medycznych nie budzi żadnych wątpliwości, gdyż służą one ochronie najwyższego dobra, jakim jest życie i zdrowie. Jeśli chodzi o dostępność, to: „W opiece zdrowotnej występują ograniczenia finansowe oraz limity zasobów, których podaż jest niewystarczająca w sposób naturalny i nie może być zwiększona przez dodatkowe finansowanie"11. Przykładem tego stanu rzeczy mogą być narządy mogące zostać użyte do transplantacji. Dostęp do wielu świadczeń medycznych jest także zależny od ekonomicznej kondycji państwa, stąd istnieje rażąca nierówność w ich dostępności pomiędzy obywatelami państw najwyżej rozwiniętych, a tymi pochodzącymi z państw najuboższych. Rynek usług medycznych w żadnym kraju nie jest także zrównoważony, gdyż popyt na nie jest niezależny od zamożności poszczególnych ludzi, a stąd przyjmuje się, że dla dobra całego społeczeństwa powinny one być reglamentowane.

Kazimierz Szewczyk wyróżnia cztery formy racjonowania świadczeń medycznych:

1) jawne - taką formą są kolejki oczekujących na deficytowe świadczenia medyczne. Każdy oczekujący wówczas wie, kiedy może się spodziewać wykonania określonej usługi.

2) niejawne - ,jego wyróżnikiem jest brak społecznie ustalonych reguł rozdzielnictwa opieki medycznej” ${ }^{12}$. W praktyce dostęp do świadczeń jest wówczas określany na zasadzie przypadku, lub dopiero przy łóżku pacjenta. Pacjenci na ogół spotykają się z taką sytuacją, gdy muszą w kolejce czekać na wizytę u określonego specjalisty.

3) ekonomiczne - występuje w dwóch formach: rynkowej i nierynkowej. Pierwsza forma oznacza wprowadzenie prawa podaży i popytu w dostępie do świadczeń. Nierynkowe racjonowanie usług wiąże się z rozdzielnictwem środków finansowych na opiekę zdrowotną w poszczególnych regionach

10 K. Szewczyк, Bioetyka, t. 2, Pacjent w systemie opieki zdrowotnej, PWN, Warszawa 2009, s. 13.

11 Tamże, s. 14.

12 Tamże, s. 26. 
państwa. Odbywa się to na zasadzie kalkulacji kosztów i lokalnych możliwości wykorzystania przyznanych zasobów.

4) nieekonomiczne - $\mathrm{w}$ racjonowaniu nieekonomicznym pod uwagę bierze się zarazem dobro pacjenta jak i dobro społeczeństwa. Kryterium dystrybucji ma więc charakter stricte moralny. Kazimierz Szewczyk za przykład podaje zapisanie pacjentowi zamiast droższego leku jego tańszego generyku wówczas, gdy pacjent nie byłby w stanie kupić leku oryginalnego. Innym przykładem jest rezygnacja z tzw. „świadczeń daremnych”, które w służbie zdrowia często są wymuszane presją pacjenta lub jego rodziny ${ }^{13}$.

Powyższa klasyfikacja uświadamia, że najmniej problemów moralnych stwarza reglamentacja jawna świadczeń deficytowych, która opiera się na istnieniu sformalizowanych kolejek oczekujących. Lista oczekujących na tego typu świadczenia jest jawna, a społeczne poczucie sprawiedliwości zaspokaja przestrzeganie przy jej ustalaniu zaledwie trzech kryteriów:

1) „kolejności zgłoszenia,

2) kategorii stanu zdrowia (ciężkość przypadku),

3) zgody pacjenta na umieszczenie go na liście"14.

Sadzić należy, że arbitralne ustalanie kategorii stanu pacjenta przez przedstawicieli medycyny jest jedynym czynnikiem, który może budzić kontrowersje w przypadku jawnej dystrybucji deficytowych świadczeń i środków. Dobrym rozwiązaniem tego problemu wydaje się ustalanie kolejności w ramach konsultacji z samymi oczekującymi. To, że przedstawiciele służby zdrowia nie korzystają $\mathrm{z}$ takich możliwości nie wynika więc, $\mathrm{z}$ jakichś zewnętrznych ograniczeń, ale raczej z ich niedostatecznych umiejętności komunikacyjnych bądź też z deficytu czasowego na ogół wynikającego z nagminnej w medycynie wieloetatowości.

Dla odmiany Jacek Hołówka wskazał, że problem sprawiedliwości w dostępie do usług medycznych nie tyle mieści się w sferze równości uprawnień, co w sferze dystrybucji: Rozważania dotyczące sprawiedliwości dystrybutywnej rozpoczać trzeba od dwóch pytań: „co podlega podziałowi?” oraz „kogo obejmuje ten podział?”"15. Podziałowi podlega zatem sfera usług, które tylko z założenia przysługują każdemu człowiekowi, a zatem formalnie obejmują całe społeczeństwo. To, ile każdemu człowiekowi przynależy swoistego pensum etycznego jest już kwestią decyzji politycznej, a nie medycznej. Sam sposób funkcjonowania systemu służby zdrowia uniemożliwia choćby równorzędny dostęp do większości usług medycznych wszystkich ludzi nawet w obrębie jednej miejscowości. Dystrybucja ograniczonego pakietu dostępnych usług jest więc konieczna, aby korzystali z nich przede wszystkim ci, którym jest ona najbardziej potrzebna,

13 Tamże, s. 18-19.

14 Tamże, s. 38.

15 J. Hoєówka, Problem sprawiedliwego podziału w rehabilitacji, „Etyka” 1975, t. 14, s. 155. 
a nie ci, którzy mają najłatwiejszy do nich dostęp. Jacek Hołówka przeanalizował problem sprawiedliwości dystrybutywnej w kontekście ludzi poddawanych zabiegom rehabilitacyjnym. Jego rozważania można odnieść do dystrybucji każdej $z$ usług medycznych. Analizie zostało poddanych pięć koncepcji sprawiedliwości dystrybutywnej znanych z filozofii. Każda z nich poddana została ocenie z uwagi na to, jak rozstrzyga dwa dylematy: „a) jak dzielić dobra i usługi pomiędzy ludźmi zdrowymi a ludźmi wymagającymi rehabilitacji, b) jak dzielić dobra i usługi w grupie osób wymagających rehabilitacji”"16 (pacjentów).

W myśl pierwszej koncepcji rozdział deficytowych świadczeń powinien odbywać się na zasadzie „każdemu wedle sumienia”, co oznaczać musiałoby zachowanie całkowitej bezstronności przy ich rozdziale, a więc zachowania najwyższych standardów moralnych w grupie decydentów. Ponieważ w tym przypadku decydentami są pracownicy służby zdrowia, to muszą oni prezentować walory moralne, które nie pozwalałyby ich nawet podejrzewać o kierowanie się w racjonowaniu świadczeń czymś innym, niż własnym sumieniem.

Kolejna koncepcja odwołuje się do zasady „każdemu tyle samo”. Jest to sprawiedliwość formalna, która w sytuacjach życiowych nie może mieć zastosowania. Radykalne stosowanie jej prowadzi wprost do sytuacji, której nikt nie może aprobować, gdy np. kapitan tonącego statku w sytuacji, gdy ma do dyspozycji mniej miejsc w łodziach ratunkowych, niż pasażerów na pokładzie, to w trosce o bezwarunkowe zachowanie zasad sprawiedliwości każe zniszczyć wszystkie łodzie znajdujące się na statku ${ }^{17}$.

Trzecia koncepcja sprawiedliwości dystrybutywnej opiera się na formule „każdemu wedle zasług”, w ogóle nie powinna być brana pod uwagę, gdyż dostęp do deficytowych świadczeń byłby formą nagrody, a odmowa - karą dla pacjenta. Przy takim korzystaniu z zasad dystrybucji największe szanse na zdobycie nagrody mieliby ci, którzy ich w danej chwili nie potrzebują, a więc ludzie zdrowi. Druga niekorzystna sytuacja wiązałaby się z przywilejami dla określonych grup lub jednostek, które miałyby gwarantowany poziom świadczeń niedostępnych w grupach pozostałych. Tego typu sytuacja zdarza się jednak w każdym państwie, a przykładem takiego stanu rzeczy są np. szpitale dla weteranów.

W kolejnej wersji sprawiedliwości dystrybutywnej obowiązuje zasada „Każdemu albo tyle, by choć minimalnie mógł skorzystać, albo nic”. Chodzi tu raczej o to, aby niesprawiedliwy podział nie był np. przyczyną niepokojów społecznych. Stąd zdaniem niektórych teoretyków prawa i moralności w sytuacji niedoboru określonych dóbr nawet na poziomie minimalnym, po prostu rezygnować z ich rozdziału. Formuła taka nie może być podstawą podejmowania decyzji, gdyż wprost prowadzi do głębokiej niesprawiedliwości. Skoro nie wszy-

16 Tamże, s. 156.

17 Zob. Tamże, s. 159. 
scy potrzebujący mają dostęp do rehabilitanta, to należałoby zamknąć wszystkie placówki świadczące tego typu świadczenia zdrowotne.

Wreszcie ostatnia przeanalizowana przez Jacka Hołówkę koncepcja opiera się na formule „Każdemu wedle jego potrzeb”. Zasada ta została sformułowana w marksizmie i choć autor z pewną sympatią pisze o niej, to jednak zawodzi w przypadku reglamentacji świadczeń medycznych, bo potrzebującymi są wszyscy obywatele. Każdy bowiem jest pacjentem, a zatem nie istnieje społeczeństwo, które byłoby w stanie zapewnić dystrybucję wedle tej formuły.

W konsekwencji należy stwierdzić, że nie istnieje żadna formuła, która zapewni sprawiedliwy rozdział deficytowych świadczeń medycznych. Można jedynie podejmować starania, aby w określonych sytuacjach kierować się którąś z przytoczonych formuł. Inną w sytuacjach kryzysowych (epidemie, katastrofy), a inną w sytuacjach codziennych. W pierwszej sprawdzić się może formuła „każdemu wedle sumienia”, a w tej codziennej „każdemu wedle potrzeb” ${ }^{18}$.

Tego rodzaju dyskusje uświadamiają bioetykom, że problemy ze sprawiedliwym podziałem środków i świadczeń medycznych często są wynikiem niedostatku edukacji etycznej personelu medycznego. Jeśli nie mają oni świadomości, że są tylko cząstką społeczeństwa, na rzecz którego wykonuje się owe świadczenia, to trudno oczekiwać jakiegokolwiek poświęcenie dla pacjentów ze strony przedstawicieli tych zawodów. Ta sama uwaga dotyczy niedostatku kompetencji komunikacyjnych, które ujawniają się tylko wówczas, gdy pacjent nie wydaje się równorzędnym partnerem w czasie terapii. Każdy proces leczniczy jest formą dialogu, w której występują dwa równorzędne podmioty, a skuteczność leczenia wynika przede wszystkim z tego, że postrzega się pacjenta jako człowieka równego sobie, a tym samym szanuje się jego niepodważalną żadnymi okolicznościami chorobowymi godność. Na tym dopiero podłożu lekarz czy pielęgniarską rzeczywiście są w stanie dokonywać rozdziału wedle formuły ,wedle sumienia”. Jest to formuła najbardziej humanitarna ze wszystkich ale wymaga, aby partnerem pacjenta była druga osoba a nie przeświadczony o własnej nieomylności, niewrażliwy na argumenty pacjenta, ekspert z zakresu medycyny.

\section{Konkluzja - „Umiesz liczyć? Licz na siebie”}

W Polsce mamy dziś rynek usług medycznych, który charakteryzuje się dynamiką zbliżoną do rynku dóbr i usług ekonomicznych. Sam rynek zaś jest: „zbiorem ludzi z obecną lub potencjalną zdolnością i pragnieniem do nabywania towarów lub usług bądź miejscem, gdzie towary lub usługi są kupowane i sprzedawane bezpośrednio lub przez pośredników” ${ }^{\prime 1}$. Z samego założenia istnienia rynku wynika

18 S. KonstańczaK, Etyka pieleggniarska, Wyd. Difin, Warszawa 2010, s. 126.

19 E. Wawelska, Kontraktowanie świadczeń pielegniarek i położnych w POZ. W: Pielęniarstwo w podstawowej opiece medycznej, pod red. D. Kiliańskiej, Wyd. Makmed, Lublin 2008, s. 38. 
możliwość nadmiernej podaży niektórych usług medycznych względnie ich niedostatku. Na ogół brak możliwości świadczenia niektórych usług medycznych ma charakter obiektywny, co znaczy, że jest niezależny od personelu medycznego, jak np. niedostatek określonej liczby dawców w transplantologii.

Problem sprawiedliwego dostępu do usług medycznych jest więc pochodną zabiegów politycznych o sprawiedliwy rozdział ograniczonych środków finansowych i materiałowych przeznaczonych na ochronę zdrowia obywateli. Skoro nie ma szansy na równy dostęp, to przynajmniej kryteria dostępności musza być czytelne i zrozumiałe dla wszystkich rzeczywistych i potencjalnych pacjentów.

Marc Lalond, były kanadyjski minister zdrowia na Światowym Forum Zdrowia wygłosił referat, w którym przedstawił wyniki badań nad długością życia poszczególnych grup ludzi. Wnioski te doprowadzily go do sformowania koncepcji pola zdrowia (field health ${ }^{20}$. W przytoczonych badaniach na zdrowie ludzi największy wpływ miały: styl życia, środowisko (społeczne i biologiczne); czynniki biologiczne (wrodzone) oraz organizacja opieki medycznej. Analizując przyczyny zgonów w Kanadzie i w innych państwach doszedł on do wniosku, iż styl życia aż w 75\% determinuje długość życia człowieka. Środowisko odpowiednio w $20 \%$ a opieka medyczna zaś tylko w $5 \%{ }^{21}$. Udowadniał też, że należy odrzucić tradycyjny punkt widzenia na determinanty zdrowia i chorób, gdyż pokładanie nadmiernych nadziei w lecznictwie powoduje, że coraz większe nakłady kieruje się na opiekę medyczną, co w świetle wyników zaprezentowanych badań jest działaniem małoefektywnym. To promocja zdrowego stylu życia i profilaktyka, przy znikomych nakładach przyniosą zdecydowanie więcej korzyści niż miliardy wydane na instytucjonalną opiekę medyczną.

Wyniki uzyskane Marca Lalonda zostały szeroko rozpowszechnione i odtąd dużo uwagi zaczęto poświęcać programom propagowania prozdrowotnych stylów życia. Zadania w tym zakresie miały do spełnienia równolegle zarówno system opieki zdrowotnej, jak i system oświaty. Cele programu propagującego zdrowy styl życia można stąd określić następująco:

1) „ «dodawać lat do życia», a więc zapobiegać przedwczesnej śmierci zarówno poprzez zwiększenie dostępności świadczeń medycznych, jak i usuwanie jej przyczyn związanych ze stylem życia,

2) „dodawać życia do lat”, co dotyczy przede wszystkim zwiększenia szans na prowadzenie przez ludzi satysfakcjonującego i twórczego życia w czasie całego okresu ich życia, a w szczególności w późniejszym wieku,

3) „dodawać zdrowia do życia”, co oznacza redukowanie ilości i intensywności zaburzeń oraz upośledzeń i niesprawności”22.

20 M. Lalond, A New Perspective on the Health of Canadians, Minister of Supply \& Services Canada, Ottawa 1974, s. 31-37.

21 Tamże, s. 33.

22 J. Melibruda, Od wydawcy. W: Ch.L. Sheridan, S.A. Radmacher, Psychologia zdrowia, s. XVIII. 
Ostatecznie problem statusu wartości sprawiedliwości jest więc nierozerwalnie związany $z$ aprobowanym statusem wartości. Nie wydaje się, aby mogły one mieć charakter obiektywny, gdyż oznaczałoby jednakowe ich odczuwanie przez wszystkich ludzi. Skoro jednak tak nie jest, to znak, że każdy jest obdarzony wolnością, z której albo nauczy się korzystać dla dobra innych i samego siebie, albo też nie. Nie można jednak tylko chcieć być sprawiedliwym, trzeba też mieć jakieś doświadczenia $\mathrm{w}$ jej odczuwaniu. Istnieje więc także problem doświadczenia moralnego, które warunkuje nie tylko postrzeganie, ale i realizację działań traktowanych jako sprawiedliwe. Dlatego też sprawiedliwości nie możemy mieć na stałe, jej ranga jest ustanowiona względnie niezależnie od nas samych, choć możemy swoim działaniem także tę rangę obniżać lub podnosić, bo jak już wspomniałem, nie ma problemu nadmiaru sprawiedliwości, a tylko problem jej niedostatku. Objawia się ona najpełniej w sytuacji swego zagrożenia, ale zawsze w ścisłym związku z pozostałymi wartościami. Możemy więc być raz sprawiedliwymi, a kolejnym razem świadomie się z tą wartością rozmijać. Nie ma ponadto przymusu bycia sprawiedliwym. Jedyny mechanizm, który skłania do przestrzegania tej wartości to ludzkie sumienie. Sprawiedliwość bowiem przejawia się w ludzkich aktach, oznacza więc zarazem pewną dyspozycję woli do jej spełniania oraz własny jej sposób rozumienia. Rozbieżność pomiędzy nimi rodzi się z niewiedzy i braku odpowiedniego doświadczenia moralnego. Nie trzeba być jednak koniecznie erudytą, aby postępować moralnie, gdyż niedostatek wiedzy zastąpić może doświadczenie, a stąd od każdego można oczekiwać sprawiedliwego postępowania. Dopiero, gdy potrafimy być tacy względem innych, to jesteśmy także $\mathrm{w}$ stanie także sprawiedliwie ocenić siebie. Jeśli zaś taka umiejętność nie została nabyta przez człowieka, to przejawia się w tym, że traktuje innych instrumentalnie jako środek służący do osiągnięcia jakiegoś celu. Dlatego tak ważna jest edukacja moralna przedstawicieli świata medycyny, gdzie wyjątkowo łatwo jest traktować drugą osobę jako przedmiot, a w konsekwencji nie zaprzątać sobie uwagi jej sprawiedliwym potraktowaniem. Nikt zatem nie nauczy się sprawiedliwości w szpitalu, szpital tylko odsłania wszystkie niedoskonałości własnej świadomości moralnej, której nie zdążyła ukształtować ani szkoła ani samodzielny wysiłek w przydawaniu sensu własnemu życiu.

Sprawiedliwy podział świadczeń i środków medycznych jest więc możliwy, bo ludzie - zarówno pacjenci jak i personel medyczny a także decydenci w kwestii tego podziału (np. politycy oraz przedstawiciele NFZ.) - są zdolni do podjęcia takiego wysiłku. Pytanie tylko, czy dla nich sama sprawiedliwość jest wartością znaczącą. Jeśli u którejś z tych stron tak nie jest, to nie można oczekiwać, że kiedykolwiek sprawiedliwy podział zostanie urzeczywistniony. Wystarczy jednak tylko zaufać potędze ludzkiego sumienia i własnej naturze skłaniającej do czynienia dobra, aby optymistycznie patrzeć w przyszłość. 